\title{
Land Reclamation and Irrigation Programs in Early Islamic Southern Mesopotamia
}

\author{
Self-Enrichment vs. State Control
}

\author{
Peter Verkinderen
}

The countryside is in the first place the locus of agriculture. Since taxation of agricultural lands amounted for the lion's share of the early Islamic empire's income, and its city-based culture was largely dependent on food (and other products) produced in the countryside, it was imperative for the empire to try and keep the countryside under control.

This paper will focus on a rather small region in southern Iraq, the area between the Persian Gulf and the great marshland called al-Bațāih. The epicenter of this region was the city of Basra, which was founded by the invading Muslims as a base for their expeditions into southern Iraq and beyond. They established their camp on the edge of the desert plateau, ca. $20 \mathrm{~km}$ west of the presentday Shaț al-'Arab (which was called the "One-eyed Tigris," Dijla al-'Awrä', at the time), and this encampment soon grew to become a mișr, a garrison city, and one of the main metropoles of the early Islamic empire.

Rural areas are heavily underrepresented in early Islamic non-documentary sources, and documentary sources from the early Islamic period are available in great quantities only for Egypt. For Iraq, close to no documentary source material has survived. However, what Iraq lacks in documentary sources is partly made up for by the extraordinary amount of attention the legal literature spends on the status of the land of the Sawād and related questions. The region of Basra in particular forms an interesting case study for the relation between the empire and the countryside because we are blessed with, in addition to the legal sources, three independent narrative sources from the Abbasid period that give us an unusually detailed insight into the exploitation of countryside of this region: Ibn Sarābiyūn's (d. after 333/945) description of the canals on both banks of the Dijla al-'Awrā'; al-Balādhurī's (d. 279/892) list of land grants and estates in the same region, focused on the Umayyad and early Abbasid period; and al-Ṭabarì's (d. 310/923) account of the Zanj rebellion (255-270/870-883) that was centred in exactly the same region. The level of detail in these three sources is to my knowledge unrivaled in the narrative sources for any rural area 
of the early Islamic empire, and taken together, they allow us to reconstruct the evolution of rural exploitation in the area.

The large investments in agriculture in the area evidenced in these sources were probably driven partly by the demand for foodstuffs for the booming city of Basra. ${ }^{1}$ But this paper argues that the investments were most of all a win-win partnership between the state and the investors: the investors were promised a high return because of a reduced tax rate for land reclamation (and the proximity of Basra as a large outlet for the produce of the land) and full ownership of the lands they reclaimed, and in return, the state received additional tax incomes from previously unproductive lands, and plentiful food supplies for one of its main cities. Probably equally importantly, controlling the access to these lucrative investments could be used by the state to reward loyal supporters and buy the loyalty of others.

\section{Land Ownership and the Muslim/Arab Conquest of Iraq}

What the Arabs called al- Irāq or al-Sawād ${ }^{2}$ is the upper part of a basin created by subduction of the Arabian plate under the Eurasian plate. The Persian Gulf occupies the largest part of this basin, but the northern part has become filled in by sediments brought down from the surrounding mountains by major rivers like the Euphrates, Tigris, and Karun. This alluvial land is very fertile, but because of the very hot and arid climate, agriculture is only possible through irrigation. ${ }^{3}$ Consequently, extending the area under cultivation requires heavy investment to construct irrigation canals.

The Sasanians invested much in irrigation in Iraq and neighboring Khūzistān. They are credited with the construction of large dams and irrigation systems ${ }^{4}$ - although it is possible that at least some of the irrigation systems

1 Hugh Kennedy, "The Feeding of the 500.0oo: Cities and Agriculture in Early Islamic Mesopotamia," Iraq 73 (2011): 177-199.

2 al-Sawād, which literally means "the blackness," is more or less synonymous to al-'Irāq; the term refers to the dark color of the cultivated land of the alluvial plain (in contrast to the light color of the surrounding desert).

3 Pieter Buringh, Soils and Soil Conditions in Iraq (Baghdad: Ministry of Agriculture, 1960), 42.

4 See among many other works: Diederik Lucas Graadt van Roggen, "Notice sur les anciens travaux hydrauliques en Susiane," Mémoires de la Délégation en Perse 7 (1905): 168-207; Ahmad Sousa, Rayy Sāmarrā’ fì 'ahd al-khilāfa al-Abbāsiyya (Baghdad: Maṭba'at al-Ma'ārif, 1948); Robert M. Adams, Land Behind Baghdad: A History of Settlement on the Diyala Plains (Chicago/London: University of Chicago Press, 1965); Robert M. Adams, "Settlement and Irrigation Patterns in Ancient Akkad," in The City and Area of Kish, ed. McGuire Gibson 
ascribed to them (both by medieval Muslim and modern authors) pre- and postdate the Sasanians. ${ }^{5}$ A combination of exhausting struggle with the Byzantine empire, internal political chaos, incursions by the Arabs/Muslims and natural disaster caused a breakdown of part of the irrigation system of the Sawād at the end of the 62os. Dams broke, the Tigris changed its course, huge expanses of cultivated land were inundated and became marshes, and the area around the former course of the Tigris became a desert. ${ }^{6}$

The collapse of the southern part of the irrigation system of Iraq coincided with the collapse of the Sasanian state and the conquest by the Muslims. If the conquest narratives are to be believed, the conquest of the Sawād took place in three major pushes, coinciding with three major battles: after coercing the Christian Arab towns west of the Euphrates into truces with the Muslims, they defeated a major army of the Sasanians at al-Qādisiyya, opening up the entire Sawād between the Euphrates and the Tigris. Then after taking the Sasanian capital Ctesiphon (called al-Madā'in by the Arabs), located on the Tigris, they also broke through this second riverine barrier. Finally the Muslims chased the Sasanian king and his army out of Iraq after defeating them at Jalūlä. ${ }^{7}$ The conquest of the southern part of Iraq and Khūzistān took place in a parallel but separate movement; no major battles are known there, which makes it more difficult to reconstruct the conquest. ${ }^{8}$

(Coconut Grove, FL: Field Research Projects, 1972), 182-208; Robert M. Adams, Heartland of Cities: Surveys of Ancient Settlement and Land Use on the Central Floodplain of the Euphrates (Chicago/London: University of Chicago Press, 1981).

5 See for example Mehrnoush Soroush, "Irrigation in Khuzistan after the Sasanians: Continuity, Decline or Transformation?" in The Long Seventh Century: Continuity and Discontinuity in an Age of Transition, edited by Alessandro Gnasso (Oxford: Oxford University Press, 2015), 269290.

6 Ibn Rusta, Kitāb al-Alāq an-nafissa (written ca. 290-30o/9o3-913), ed. Michael Jan de Goeje (Leiden: Brill, 1892), 89 f.; Ibn al-Faqīh al-Hamadhānī, Kitāb al-Buldān (written ca. 29o/902903) (Mashhad ms.), ed. Zacharias van Laer (Brussels: author's edition, 1985), 2:296; Qudāma b. Jaffar (d. ca. 319/932), Kitāb al-Kharāj, ed. Michael Jan de Goeje (Leiden: Brill, 1967), 240; Yāqūt al-Rūmī, Mújam al-buldān (Beirut: Dār Ṣādir, 1977), 1:451, 2:179. See also Werner Nützel, "The End of the South Mesopotamian Civilizations Caused by the Bursting of the Dykes of the Euphrates and Tigris in 629AD," Sumer 38 (1982): 144-151; and, more recently, Peter Verkinderen, Waterways of Iraq and Iran in the Early Islamic Period:Changing Rivers and Landscapes of the Mesopotamian Plain (London: I.B. Tauris, 2015), 50-54.

7 The precise chronology of the conquest of central al-'Irāq is unclear; the Battle of al-Qādisiyya is dated to the years $13 / 635,14 / 636$ and $16 / 637-638$ by different sources; the siege of al-Madāin is said to have lasted for two or 28 months; but at least all sources agree that the Battle of Jalūlā took place after the fall of al-Madāin, according to some as early as the end of the year 16/638, according to others only in the year 19/640. See Fred M. Donner, The Early Islamic Conquests (Princeton: Princeton University Press, 1981).

8 See Donner, Conquests; Chase F. Robinson, "The Conquest of Khûzistân: A Historiograph- 
With the Sasanian overlords driven out of the plain, Iraq was quite literally decapitated. The basic structure of society survived, however: most of the inhabitants were sedentary peasants called al-nabat or al-anbāt in the Arabic sources, an ethnically diverse, Aramaic-speaking group. Most of these were probably attached to the soil they cultivated, which was organized in village estates (Pers. dèh) granted by the state to a primarily Persian landholding lower nobility (Ar. dahāqūn, sg. dihqūn < Pers. dēhīk, dēhkānān). The population of the cities was also predominantly Aramaic-speaking. ${ }^{9}$

The ownership of the lands of the Sawād seems to have been a hotly debated legal question in the Umayyad period, probably because it had far-reaching consequences for the income the state derived from the land tax. We find the traces of these debates in our earliest legal sources, which date from the early Abbasid period. It appears that Umayyad jurists tried to rationalize and codify existing divergent fiscal practices related to the Sawād lands, and by the early Abbasid period, a system of three categories of land was firmly in place. ${ }^{10}$

Firstly, șulh ("treaty") lands, kept in full ownership of the inhabitants, in return for a fixed tax, specified in a treaty with the Muslims. According to the jurists, only a very few localities in the Sawād like al-Hīra, Bāsimmā, and al-Anbār (all located on the western edge of the Sawād, and in the hands of sedentary Arabs before the conquest) had such a treaty.

Most of the Sawād, however, was considered to have been conquered by force ('anwatan). These lands were reportedly temporarily distributed among the tribes that took part in the conquest, but soon after - apparently under 'Umar b. al-Khațāa (r. 13-23/634-644) - they were put under control of the state; reasons given for this in the sources are concern with the livelihood of later generations of Muslims, and fear for internal fighting over the dis-

ical Reassessment," Bulletin of the School of Oriental and African Studies 67 (2004): 14-39; Hugh Kennedy, The Great Arab Conquests (Philadelphia: Da Capo Press, 2007); Parvaneh Pourshariati, The Decline and Fall of the Sasanian Empire (London: I.B. Tauris, 2008).

See Michael Morony, Iraq after the Muslim Conquest (Princeton: Princeton University Press, 1984); Michael Morony, "Landholding and Social Change: Lower al-'Irāq in the Early Islamic Period," in Land Tenure and Social Transformation in the Middle East, ed. Tarif Khalidi (Beirut: American University in Beirut, 1985), 209-222.

See the works on kharāj by the jurists Abū Yūsuf (d. 182/798) and Yahyā b. Ādam (d. 202/ 818) (Abū Yūsuf, Kitāb al-Kharāj (Cairo: al-Mațbáa al-Salafiyya, 1933) and Yahyā b. Ādam, Kitāb al-Kharāj, ed. and trans. Aharon Ben Shemesh as: Taxation in Islam 1: Yahya ben $\bar{A} d a m$ 's Kitāb al-Kharāj (Leiden: Brill, 1958)) ; and the discussion of the concepts of kharājj, 'ushr, fay', and ghanīma in the compendia of Qudāma and al-Māwardī (d. 450/1058). Interesting discussions can be found in Werner Schmucker, Untersuchungen zu einigen wichtigen Bodenrechtlichen Konsequenzen der Islamischen Eroberungsbewegung (Bonn: Selbstverlag des Orientalischen Seminars der Universität Bonn, 1972); Morony, Iraq; and Donner, Conquests. 
tributed lands. ${ }^{11}$ An underlying reason may have been that many peasants who worked these lands and had been attached to the soil, and many local noblemen (dahäqīn) who owned the land, had fled, rendering the uncultivated lands worthless as a source of liquid income for the conquerors. ${ }^{12}$ The farmers and dahāqin of these lands, still according to the jurists, were given a protected status (dhimma), and a land tax (kharäj), comparable to the Sasanian land tax, was imposed on the land. ${ }^{13}$ The collection of the tax was left in the hands of the dahāqin, who probably fulfilled the same function under the Sasanians. ${ }^{14}$

The precise status of this category of land was a contested affair throughout the early Islamic period, mirroring conflicting interests of the state, the descendants of the conquerors, and converts to Islam: al-Māwardī (d. 450/1058), who gives an overview of the main legal opinions to this question, states that the 'Irāqi jurists said the land was returned to the hands of the owners (i.e., the dahāqin), who could dispose of it as they wished as long as kharäj was paid on it, but (still according to al-Māwardī) some Shāfi'i jurists claimed that the land was kept in the hands of the state, and the kharāj was a kind of rent paid to the state, which implies the land could not be sold. ${ }^{15}$ Other questions arose around these kharājlands, to which the jurists came up with conflicting answers: if the owner of a piece of land converted to Islam, should he still pay the kharäj, or rather the lighter 'ushr tax? And similarly, if kharāj land was bought by a Muslim, did he have to pay kharāj or 'ushr?'16

Finally, there were the șawāfi (sg. șāfiya), the "crown lands," lands that did not belong to a private owner after the conquest (anymore), and were supposedly confiscated by the caliph 'Umar b. al-Khațāa for the Islamic state: this category includes marshes and other uncultivated areas, lands that belonged

\footnotetext{
11 See Schmucker, Untersuchungen, 101-123, for an overview of the arguments.

12 This reason is reflected in admonitions ascribed to 'Umar I to the conquerors to treat the peasants well and his reported attempts to bring them back to the lands they had fled. See Schmucker, Untersuchungen, 101-123.

13 The classical study on the kharäj is Frede Løkkegaard, Islamic Taxation in the Classic Period (Copenhagen: Branner og Korch, 1950). For a more recent take on the kharäj, see Ghaida Khazna Katbi, Islamic Land Tax al-Kharäj: From the Islamic Conquests to the Abbāsid Period (London: I.B. Tauris, 2010).

14 See Michele Campopiano's article in this volume.

15 al-Māwardī, al-Aḥkām al-sulțāniyya, ed. Maximilianus Enger (Bonn: Adolphus Marcus, 1853), $302 \mathrm{f}$.

16 Most jurists judged that kharäj still was to be paid, in order not to reduce the state income. For a good overview of the jurists' questions related to the kharāj, and their conflicting answers to these questions, see the chapters 12-14 of al-Māwardī's al-Ahkām al-sulțāniyya.
} 
TABLE 15.1 Legal status of lands in al-Sawād

\begin{tabular}{|c|c|c|c|c|}
\hline șulh lands & \multicolumn{4}{|c|}{ 'anwa lands } \\
\hline Treaty, not & \multicolumn{4}{|c|}{ Conquered by military force } \\
\hline \multicolumn{2}{|c|}{ Village estates } & \multicolumn{3}{|c|}{ șawāfi } \\
\hline \multirow{2}{*}{\multicolumn{2}{|c|}{$\begin{array}{l}\text { Pre-islamic landholding system } \\
\text { maintained }\end{array}$}} & \multicolumn{3}{|c|}{$\begin{array}{l}\text { Lands without private owner (owners fled or were killed } \\
\text { during conquests; marshes; public places) }\end{array}$} \\
\hline & & State lands & Private estates & Barren land \\
\hline \multicolumn{2}{|c|}{ Agriculturally diversified } & \multicolumn{2}{|c|}{$\begin{array}{l}\text { Mono-culture of labor-intensive cash } \\
\text { crops }\end{array}$} & $\begin{array}{l}\text { Uncultivated (but: } \\
\text { fishing, hunting, } \\
\text { reed gathering) }\end{array}$ \\
\hline \multicolumn{2}{|c|}{ Relatively self-sufficient } & \multicolumn{2}{|c|}{ Market-oriented } & \\
\hline \multirow[t]{2}{*}{$\begin{array}{l}\text { Held by pre- } \\
\text { islamic owners } \\
\text { (Arabs) }\end{array}$} & $\begin{array}{l}\text { Held by pre- } \\
\text { islamic owners } \\
\text { (non-Arab } \\
\text { dahāqīn) }\end{array}$ & Held by the state & $\begin{array}{l}\text { Granted to private } \\
\text { persons }\end{array}$ & Held by the state \\
\hline & $\begin{array}{l}\text { Worked by servile } \\
\text { renting tenants }\end{array}$ & $\begin{array}{l}\text { Worked by } \\
\text { sharecroppers or } \\
\text { slaves }\end{array}$ & $\begin{array}{l}\text { Worked by renting } \\
\text { tenants or slaves }\end{array}$ & $\begin{array}{l}\text { Worked by free } \\
\text { elements? }\end{array}$ \\
\hline $\begin{array}{l}\text { Paid a fixed } \\
\text { amount of taxes as } \\
\text { prescribed in the } \\
\text { treaty }\end{array}$ & $\begin{array}{l}\text { Paid harāj, } \\
\text { collected by } \\
\text { dahāqīn }\end{array}$ & $\begin{array}{c}\text { Paid between } 1 / 3 \\
\text { and } 1 / 2 \text { of the crops } \\
\text { to the state }\end{array}$ & $\begin{array}{c}\text { Paid 'ušr (tithe) to } \\
\text { the state }\end{array}$ & No taxes \\
\hline $\begin{array}{l}\text { Only very few Arab } \\
\text { towns on the w } \\
\text { edge of the Sawād: } \\
\text { al-Hīra, al-Anbār, } \\
\text { Ullais, etc. }\end{array}$ & $\begin{array}{l}\text { Majority of the } \\
\text { Sawād lands; } \\
\text { mostly in Sawād al- } \\
\text { Kūfa and Middle } \\
\text { Tigris }\end{array}$ & $\begin{array}{l}\text { Scattered through } \\
\text { Sawād, but } \\
\text { enlarged mainly by } \\
\text { reclamation from } \\
\text { the Bațịhat Wāsit }\end{array}$ & $\begin{array}{l}\text { Mostly reclaimed } \\
\text { land around } \\
\text { al-Bașra }\end{array}$ & Mostly al-Bațāìh \\
\hline
\end{tabular}

ADAPTED FROM MORONY, IRAQ 
to people who were killed or fled during the conquest war (including the Sasanian royal family and high nobility), and public spaces like mints, post stations, and water cisterns. ${ }^{17}$

The kātib Qudāma (d. ca. 319/932) and the geographer Ibn Hawqal (d. after 378/988) tell us that the entire area of Basra, which is the focus of this study, was considered "dead land" (mawāt), ${ }_{18}^{18}$ a specific type of șawā that was not cultivated and did not have any other function. These lands were considered property of God and thus of the state by the legal scholars. ${ }^{19}$

Because they were barren, dead lands did not yield tax money for the treasury. In order to make money from these lands, the state could invest in reclaiming them by digging irrigation canals and drains, and have the land cultivated for the state by sharecroppers or slaves. Interestingly, this kind of state investment is known from other areas of the Sawād, ${ }^{20}$ but not mentioned in the area of Basra. Here, the only canal-digging activities explicitly said in the sources to be state enterprises were efforts to bring drinkable water to the city of Basra. ${ }^{21}$

Another solution to raise its income from the șawäf $i$ was found. Dead lands were granted to private persons, who would then invest their own money in reclaiming the land and cultivating it. In return for this service, the investor

17 Yahyyā b. Ādam, Kharāj, tr. 45f., ed. 197-199; Qudāma b. Ja far, Kitāb al-Kharāj, ed. and trans. Aharon Ben Shemesh as: Taxation in Islam 2: Qudāma b.Jafar's Kitāb al-Kharāj, part seven, and excerpts from Abū Yūsuf's Kitāb al-Kharāj (Leiden: Brill, 1965), F. 85v . On the administration of these șawäf $\iota$ after the conquest, see Morony, Iraq, 68-70.

18 Qudāma, al-Kharāj, F. 85v ( fa-inna al-Bașra kulluhā kānat yawma’idhin sibākhan (...) waal-sibākh mawāt); Ibn Ḥawqal, Kitāb Șūrat al-ard, ed. Johan Hendrik Kramers (Leiden: Brill, 1938), 236.

19 al-Māwardī, Aḥkām, 308.

20 One of the more striking examples is Abu Ahmad al-Muwaffaq's investment in the ruined al-Ṣilḥ and al-Mubārak districts near Wāsiț, with the explicit aim of financing the war against the Zanj. The investment included the digging of canals and the providing of seeds and cattle to the poorest of the cultivators (al-akara wa-al-tunnä’ wa-al-muzäri'in) (alQāọī al-Tannūkhī, Nishwār al-Muhạậara, ed. 'Abūd al-Shaljī (Beirut: Dār Ṣādir, 1971-1973), 8:153-155).

21 E.g. Ibn al-Faqīh, Buldān (Mashhad ms.), 1:41; al-Balādhurī, Kitāb Futūḥ al-buldān. ed. Michael Jan de Goeje as: Liber expugnationis regionum (Leiden: Brill, 1968), 369; Yāqūt, Buldān, 5:305; Ibn Rusta, A`đāq, 89; Ibn Ḥazm al-Andalusī, Jamharat ansāb al-'arab, ed. Évariste Lévi-Provençal (Cairo: Dār al-Macārif, 1948), 97. 
did not have to pay the land tax (kharāj), only the much lighter 'ushr (tithe). ${ }^{22}$ This was a win-win situation: the state did not have to spend huge amounts of money and labor on the reclamation of lands, while it did receive tax money from lands that previously did not make any money. An additional advantage for the government would be that it could use grants of these dead lands to gain the support of powerful persons, or reward them for their continuing support. For the reclaimer this was a very interesting investment, because it promised a high profit since the tax on the reclaimed lands was lower than on kharāj lands, and, perhaps even more importantly, he received the land in full ownership, which meant it could be sold, inherited, mortgaged, etc. This was not always the case for other kinds of land in Iraq.

Such piece of dead land granted to a private person was called a qațía. ${ }^{23}$ Al-Mâwardī contrasts the early Islamic qațīa with the land grant type that was current in his own time, the $i q t \bar{a}$ ' by which only the right was granted to appropriate the tax income of a certain area subject to kharajj, and only for a limited amount of time; the land itself stayed in the possession of its owners, and could not be sold, mortgaged etc. by the grantee. ${ }^{24}$

Al-Māwardī nuances the claim by Ibn Ḥawqal and Qudāma that all of Basra's land was 'ushr land. In his account, it is "land that has been revived of the mawät (dead lands) and sibākh (salt flats) of Basra" that is all 'ushr land. ${ }^{25} \mathrm{He}$ also writes that the only reason why these lands were subject to 'ushr is that they consisted of reclaimed land, refuting the theories of a number of other jurists (including Abū Ḥanīfa (d. 150/767) and Abū Yūsuf (d. 182/798)) that the rea-

22 How did the reclamation of land work in practice? Al-Māwardī (Aḥkām, $308 \mathrm{f}$.) sets three conditions for land to be considered reclaimed: (1) the land needs to be marked off by heaping soil along its boundaries; (2) it needs to be supplied with water if it is too dry, or drained if it is too wet; and (3) it needs to be leveled and ploughed. Only after the third step was finished, the land was considered reclaimed. If the reclaimer waited for more than 3 years before finishing the reclamation, he lost his title to the land.

23 See Cahen's article "Iktā" in the Encyclopaedia of Islam for a more detailed discussion of the evolution of the iqță system (Claude Cahen, "Iḳtāe," in Encyclopaedia of Islam, 2nd ed. (Leiden: Brill), http://dx.doi.org/10.1163/1573-3912_islam_SIM_3522). Note that qațīa is often wrongly translated by the word "fief" of the European feudal system, which was quite different from the Early Islamic system. The corresponding European technical term for land that is held in absolute ownership is "allod" or "allodium" (Hugh Kennedy, personal communication, 28 October 2009).

24 For this reason, al-Māwardī calls the $i q t \bar{a}^{c}$ of his time $i q t \bar{a}^{c} i s t i g h l a \bar{l}$ (usufruct grant) and the early Islamic system $i q t \bar{a}^{c}$ tamlīk (grant of which the grantee gets the full ownership, mulk).

al-Māwardī, Aḥkām, $311 \mathrm{f}$. 
son was the fact that the entire area was irrigated by ush $r$ water. ${ }^{26}$ Indeed, not the entire area of Basra can have been dead/'ushr land. At the time of the conquest, a number of towns (the most important being al-Ubulla and al-Madhār) were located in the area, and these must have been surrounded by fields. One special case, mentioned by al-Balādhurī (d. 279/892), relates to some lands in al-Furāt (the name for the east bank of the Dijla al-'Awrâ), where kharāj land had become 'ushr land after the conquest. The Umayyad governor al-Hajjaj b. Yūsuf (in office 75-95/694-714) later turned it back into kharäj land, and the land kept oscillating between 'ushr and kharäj status until the Abbasid caliph al-Mahdī (r. $15^{8-169 / 775-785)}$ turned it into ushr land once and for all. ${ }^{27}$ Nevertheless, kharäj lands appear to have been a marginal phenomenon in the Bașra area.

Let us now leave the theories of the jurists behind, and focus on the geographical and historical sources.

\section{Reconstructing the Chronology of the Investments: a Geographical Approach}

The first of these accounts is a description of the Dijla al-'Awrä' by the fourth/ tenth-century geographer Ibn Sarābiyūn (d. after 333/945). He lists the ten main canals on the west bank of the river, including the distances between the canals. ${ }^{28}$ Six of these canals can be identified by way of modern toponymy and traces of ancient canals on satellite images. The approximate location of the other three is easily found by the distances mentioned by Ibn Sarābiyūn. ${ }^{29}$

26 The basis for the other jurists' views is that according to one of the tax rules, lands irrigated with water from the main rivers and from pre-Islamic canals were to be considered kharāj land. In the Basra area, however - the jurists say - all of the canals were dug after the conquest. Moreover, the water from the Tigris and Euphrates discharged into the alBațầih marshes, where it lost its kharāj character. From the Bațāih, the water seeped into the Dijla al-'Awrā', the former Tigris estuary, from where it was pushed into the canals by the tide. Since the sea nor the marshes are kharäj waters, all of the lands of Basra were only subject to 'ushr. al-Māwardī does not deny all this is true, but stresses the principle that reclaimed land is subject to 'ushr, not kharäj, irrespective of the source of its irrigation water.

27 al-Balādhurī, Futūḥ, 368.

28 Ibn Sarābiyūn, Kitāb Ajā̉ib al-aqālim al-sab'a, ed. Hans von Mžik (Leipzig: Otto Harassowitz, 1929), $136 \mathrm{f}$.

29 See Verkinderen, Waterways, 75-100; and Fig. 15.1. 


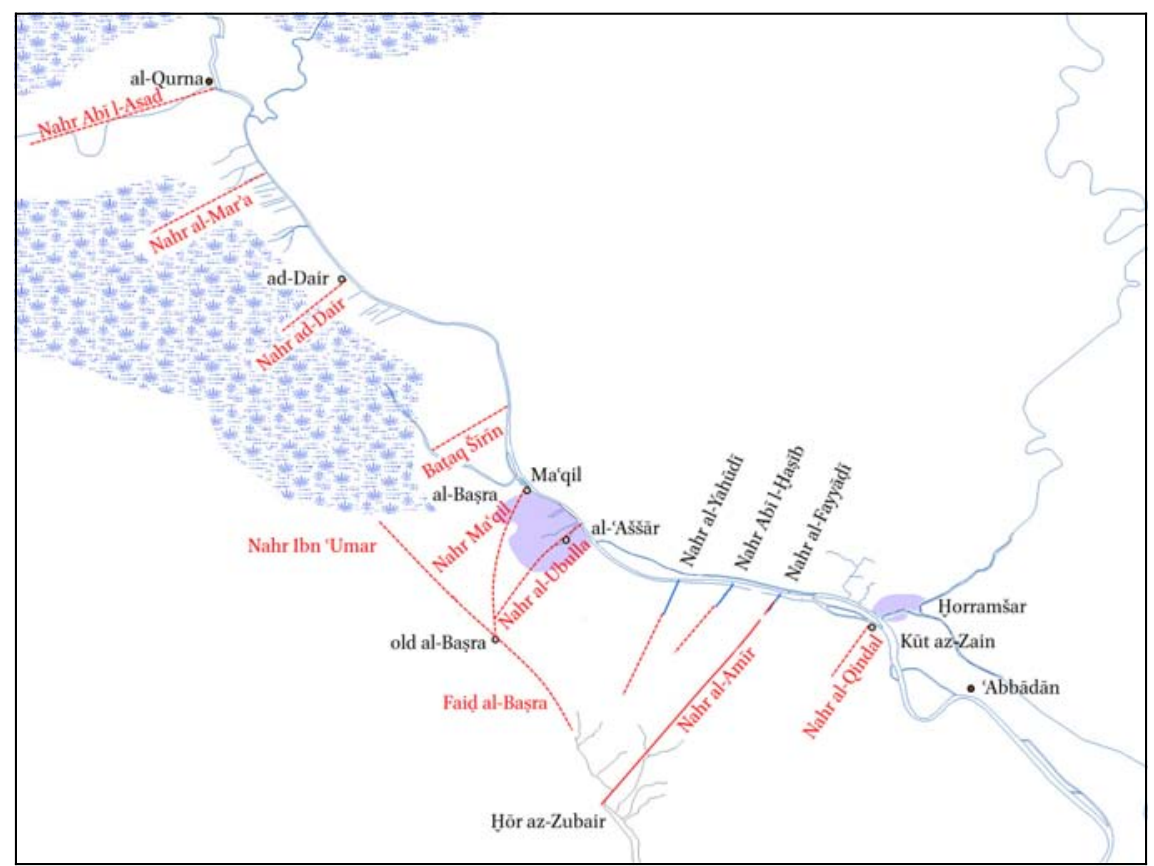

FIGURE 15.1 The main canals on the West bank of the Dijla l-'Awrä' (black and blue: modern names and watercourses; red: Early Islamic canals)

A quick look at these canals (from north to south) and their dates is revealing:

- The Nahr Abì al-Asad was the main connection between the marshes and the Dijla al-'Awrä'. It was named after a commander of the Abbasid caliph al-Ma’mūn, but Yāqūt states this Abū al-Asad only widened an existing channel. ${ }^{30}$

- The Nahr al-Mara may have been pre-Islamic, because it is mentioned in the accounts of the conquests as the location of a castle of a female landowner. ${ }^{31}$

- The Nahr al-Dayr existed already before Nahr Ibn 'Umar was dug in 126/ $744{ }^{32}$ and probably already in the pre-Islamic period, since the canal was

30 Yāqūt, Buldān, 5:305; Ibn 'Abd al-Ḥaqq al-Baghdādī, Marāṣid al-Iț̣ilā', ed. 'Alī Muhammad al-Bijāwī (Cairo: Dār al-ma'rifa, 1954), 1399.

31 al-Balādhurī, Futūh, 340; al-Ṭabarī, Mukhtașar tảrīkh ar-rusul wa-al-mulūk wa-al-khulafä’, ed. Michael Jan de Goeje (Leiden: Brill, 1964), series I, 2025f., 2381; Khalīfa b. Khayyāt, Ta’rīkh, ed. Mușțafā Naj̄̄b Fawwāz and Ḥikmat Kishlī Fawwāz (Damascus: Dār al-kutub al-ilmiyya, 1995), 86; Yāqūt, Buldān, 1:431, 5:323. Of course, it cannot be ruled out that the story about the female landowner is a result of folk etymology. al-Balādhurī, Futūḥ, 37o. 
named after a pre-Islamic monastery called Dayr al-Dihdār that was located at its entrance. ${ }^{33}$

- The Bathq Shīrin is said to be named after a slave girl of the Persian king Kisrā Abarwīz, ${ }^{34}$ which would imply that it predates Islam. At the very least, it existed before the Basran governor 'Adī b. Arțāh (in office 99-101/718-720) dug a canal from Bathq Shīinn to Basra in order to improve the water supply to the city. ${ }^{35}$

- The Nahr Ma'qil was one of the main canals that connected the city of Basra to the Dijla al-'Awrä'. It was reportedly dug by Ziyād b. Abīhi when he was the deputy of governor Abū Mūsā (in office 17-29/638-650) or when he was governor of Basra himself (in office $45-53 / 666-672$ ). ${ }^{36}$

- The Nahr al-Ubulla was Basra's other main canal, and was dug by governor Abū Mūsā al-Ash'arī (in office 17-29/638-650) 37 and Ziyād b. Abīhi, deputy of governor 'Abd Allāh b. 'Āmir (in office $29-35 / 650-656$ ). ${ }^{38}$

- The Nahr Ibn 'Umar, also known as the Fayḍ al-Bașra, was dug by 'Abd Allāh b. 'Umar b. 'Abd al-'Azīz (son of the caliph 'Umar II, and governor of Basra, in office $126-127 / 744-745)$ in the year $126 / 744{ }^{39}$

- The Nahr al-Yahūdī probably predates the Nahr Nāfidh which belonged to the governor 'Abd Allāh b. 'Āmir (in office 29-35/650-656). ${ }^{40}$

- The Nahr Abī al-Khașīb was named after a mawlā, client, of the Abbasid caliph al-Manșūr (r. 137-158/754-775). ${ }^{41}$

- The Nahr al-Amīr was dug at the order of al-Manșūr. ${ }^{42}$

- The Nahr al-Qindal used to be a natural creek. Al-Mundhir b. al-Zubayr b. al'Awwām (d. 61/68o) had a qațía along it. He was the brother of the Zubayrid

33 Yāqūt, Buldān, 2:509, 5:320; al-Baghdādī, Marāṣid, 558, 56o.

34 al-Balādhurī, Futūḥ, 367; Yāqūt, Buldān, 5:321.

35 Yāqūt, 5:321.

36 al-Balādhurī, Futūh, 358; al-Balādhurī, Ansāb al-ashrāf, ed. Suhail Zakkar and Riyāẹ Ziriklī (Beirut: Dār al-fikr, 1996), 2:331f.; Yāqūt, Buldān, 5:324; al-Baghdādī Ibn 'Abd al-Ḥaqq, Marāṣid, 1406.

37 Ibn al-Faqīh al-Hamadhān̄̄, Kitāa al-Buldān, ed. Michael Jan de Goeje (Leiden: Brill, 1885), 189 f.; al-Balādhurī, Futūh, 356 f.; Yāqūt, Buldān, 5:316f.

38 al-Balādhurī, Futūh, 357; Yāqūt, Buldān, 2:65, 5:316 f.

39 al-Hamadhānī, Buldān (Mashhad ms.), 1:41; al-Balādhurī, Futūḥ, 369; Ibn Rusta, Álāq, 89; Yāqūt, Buldān, 5:305; al-BaghdādīMarāṣid, 1399; al-Ḥāzimī, Mā ittafaqa lafžuhu waiftaraqa musammāhu fì al-amākin wa-al-buldān al-mushtabiha fì al-khațt, ed. Fuat Sezgin (Frankfurt am Main: Institute for the History of Arab and Islamic Science, 1986), 97. al-Ṭabarī, Ta’ī̄kh, 3:2022; al-Balādhurī, Futūḥ, 36o; Yāqūt, Buldān, 5:324; al-Baghdādī, Marāṣid, 1407 .

41 al-Balādhurī, Futūh, 362; Yāqūt, Buldān, 5:305.

42 al-Balādhurī, Futūḥ, 362; Yāqūt, Buldān, 5:317; al-Baghdādī, Marāṣid, 1400. 
(counter-)caliph 'Abd Allāh b. al-Zubayr (64-72/683-692) and Muș'ab, who was governor of Basra (in office 67-71/686-691). It was dammed by the

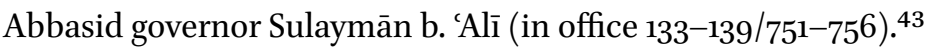

The date of the northernmost canal, Nahr Abi al-Asad, is not known, except that it predates al-Ma'mūn's reign. The next three canals may predate Islam. Those closest to the city of Basra were dug in the first years after the city was founded, in order to bring sweet drinking water to it. Finally, the three southernmost canals were constructed only under the Abbasids. The chronological and geographical spread of the canal building activities suggests that most of the west bank of the river was brought under extensive cultivation during the first 15 o years of Islam. ${ }^{44}$ Unfortunately, the information about the four canals that Ibn Sarābiyūn mentions on the east bank of the Dijla al-'Awrā is less complete; we can only date one canal, the Nahr al-Mubārak, which was reportedly dug by governor Khālid al-Qasrī (in office ca. $\left.105^{-120} / 723-73^{8}\right),{ }^{45}$ and none of the canals can be located with certainty. ${ }^{46}$

\section{Who is Who in the Land-Owning Business? al-Balādhurī's List of Estates near Basra}

A second important source is al-Balādhurīs list of the canals and estates of Basra, ${ }^{47}$ which is based mainly on the works of al-Walīd b. Hishām b. Qahdham (known as al-Qaḥhamī, d. 222/837), 'Alī b. Muhammad al-Madāinī (d. 225/ 840), and a small number of other Basran akhbārīs, and is heavily concentrated on the Umayyad period. The list contains ca. 150 places in the area of Basra of which al-Balādhurī tries to identify the persons after whom they were named. The list is not ordered by a single clear principle. It starts with the two main

43 al-Balādhurī, Futūh, 363; al-Balādhurī, Ansāb al-ashrāf, ed. 'Abd al-'Azīz al-Dūrī (Beirut: Deutsche Morgenländische Gesellschaft, 1978), 123.

44 The entire area between these canals (each of which was between 15 and $20 \mathrm{~km} \mathrm{long}$ ), measures about $1500 \mathrm{~km}^{2}$. For an overview of the area covered by traces of these canals and fields, mapped from satellite imagery, see Verkinderen, Waterways, plate 4a.

45 al-Hamadhānī, Buldān (Mashhad ms.), 1:63; Yāqūt, Buldān, 5:5of.; al-Baghdādī, Marāṣid, 1225 .

46 It is therefore more difficult to make an estimate of the total area under cultivation on the east bank in this period. On satellite imagery, fossil traces of cultivation very similar to those on the west bank that have been identified as probably belonging to the early Islamic period, can be seen stretching out for a distance of ca. $70 \mathrm{~km}$, with a maximum inland extent of ca. $12 \mathrm{~km}$. Cf. Verkinderen, Waterways, 73-75, and plate 4 a.

al-Balādhurī, Futūḥ, 356-372. 
canals dug by the first governors of Basra in order to provide the city with fresh water, Nahr Ma'qil and Nahr al-Ubulla, followed by further developments of the area around these two canals. But after that, a geographical or chronological order is not to be found; rather, the $a k h b \bar{a} r$ are ordered by association, or sometimes simply juxtaposed; from time to time some $a k h b \bar{a} r$ are clustered thematically.

Michael Morony has used this source to trace the social history of a new landlord class created in Basra through land grants by the authorities. ${ }^{48}$ Some caution is needed when using this list for a study of landholding though. Only in a minority of cases the places are explicitly labeled qați $a$. More often, the place is said to be named after or to have belonged to the person after whom it was named, without stating the relation of the person with the land. After all, al-Balādhurī mentions, besides qațẳi' also canals dug to convey drinking water to the city, dead lands revived without permission of the authorities, and $a w q \bar{a} f$, pious endowments. Moreover, places in the list are not necessarily named after the receiver of the land grant. Some of the lands are explicitly said to have been named after the person tasked with the practical reclamation of the land, a person who later bought the property, or persons otherwise connected to the place. Consequently, we cannot automatically identify any of the unspecified place names as a qaticia belonging to the person after which it was named. Only in a very limited number of cases, al-Balādhurī offers information about the history of the estate. Other questions, however, remain open: Did it stay in the family? Was it confiscated when the family fell out of grace with the rulers or at the time of a regime change? Was it sold to someone else? To make things even more complicated, most of the places are called $X$-ān (a typically Basran way to derive a nisba adjective from a personal name, e.g. Dāwūdān $)^{49}$ or $N a h r X$, both of which can refer to a canal or a canal and the estate that was located along it, and sometimes more than one estate was located on a canal.

Keeping this caveat in mind, the list offers a wealth of information about landholding in the Basra area. It is very instructive to take a look at who gives and who receives land grants in the Basra area. The only persons explicitly said to grant lands in the list are Umayyad-period governors of Basra, ${ }^{50}$ their

\footnotetext{
48 Morony, "Social Change."

49 See Yāqūt, Buldān, 1:189.

50 'Abd Allāh b. 'Āmir (in office 41-44/661-664), Ziyād b. Abī Sufyān (in office 45-53/665673), al-Ḥajjāj b. Yūsuf (75-95/695-714). For a list of governors of al-Bașra, see Charles Pellat, Le milieu bașrien et la formation de Ğāhiz (Paris: Adrien-Maisonneuve, 1953).
} 
deputies, ${ }^{51}$ and the caliphs. ${ }^{52}$ In a very limited number of cases, a piece of land was granted by person who is not a governor or caliph (e.g. the army commanders al-Muhallab and 'Uthmān b. Abī al-Āṣī), but in these cases the granter probably received the qatî $a$ from the caliph or governor, and passed part of it on to family and/or friends..$^{53}$ Thus, al-Balādhurī's text suggests that after a period during which the powerful governors Ibn 'Āmir, Ziyād, and al-Hajjāj had the right to grant dead lands, this privilege became concentrated in the hands of the caliphs by the end of the first/seventh century.

The grantees form a more heterogeneous group. In more than $80 \%$ of the places in the list, an owner of the place can be identified - even if we cannot be sure they had received the land as a grant. Governors and their families and mawāli form a large subgroup. ${ }^{54}$ Another group of grantees fulfilled other important functions in the (provincial) government: judges ( $q \bar{a} d \bar{l} \bar{s}),{ }^{55}$ guard/police chiefs (așhāb al-shurța), ${ }^{56}$ army commanders (amìrs). ${ }^{57}$ Even the Barmakids, the powerful vizier family serving the Abbasids, held an important grant in Basra (an estate called Sayḥān), as did some of the caliphs (Hishām b. 'Abd al-Malik, al-Manșūr). Other categories of people with a high standing

51 Ziyād b. Abīhi/Abī Sufyan (under 'Abd Allāh b. ‘Āmir's governorship), 'Ubayd Allāh b. Abī Bakra (in office 61-64/681-684).

52 'Umar (r. 13-23/634-644), 'Uthmān (r. 23-35/644-656), Mu'āwiya (r. 41-61/661-68o), Yazīd b. Mucāwiya (r. 6o-64/68o-683), 'Abd al-Malik b. Marwān (r. 65-86/685-705), Sulaymān (r. 96-99/717-717), Yazīd b. 'Abd al-Malik (r. 101-105/720-724), Hishām b. 'Abd al-Malik (r. 105-125/724-743), Abū al-'Abbās (r. 132-136/750-754), al-Manșūr (r. 137-158/754-775), al-Mahdī (r. 158-169/775-785), Hārūn al-Rashīd (r. 170-193/786-809), al-Ma’mūn (r. 198218/813-833).

53 E.g., al-Muhallabān was given by al-Muhallab to his wife (al-Balādhurī, Futūḥ, 36o); and Ḥaf̣̦ān, Umayyatān, Ḥakamān and Mughīratān were given by 'Uțmān b. Abī al-'Āṣi to his sons (al-Balādhurī, Futūh, 362).

54 'Abd Allāh b. 'Āmir, Ziyād b. Abīhi and his half-brothers Abū Bakra (d. ca. 52/672) and Nāfi (d. 5o/67o), 'Umar b. 'Ubayd Allāh b. Ma'mar b. 'Uthmān (in office 64-68/683-687), Ḥumrān b. Abān (in office ca. 71/691), Khālid b. 'Abd Allāh b. Khālid al-Asīd (in office 72-73/691-693), al-Ḥajjāj b. Yūsuf, Yazīd b. al-Muhallab (in office 96-99/715-717), 'Adī b. Arțāh (in office ca. 95-96/713-715), 'Umar b. Hubayra (in office 102-105/720-724), 'Abd Allāh b. 'Umar b. 'Abd al-'Azīz (in office 126-127/744-745), Sufyān b. Mu'āwiya b. Yazīd b. al-Muhallab (in office 132/749), and the Abbasids Sulaymān b. 'Alī b. 'Abd Allāh (in office 133-139/750-756) and his son Muhammad (in office 16o-163/776-779). e.g. 'Umayra b. Yathribī al-Ḍabbī (under 'Abd Allāh b. 'Āmir), Khālid b. Ṭulayq b. Muhammad b. 'Amrān (in office 167/783-784).

$5^{6}$ Yazīd b. 'Umar al-Usayyidī (in office ca. 86-93/705-711), Shaybān b. 'Abd Allāh al-Aḥmasī (in office under 'Ubayd Allāh b. Ziyād), 'Ubayd b. Qusayț (in office under al-Hajjāj). For a list of the shurța commanders of Basra, cf. Michael Ebstein, "Šurța Chiefs in Bașra in the Umayyad Period: A Prosopographical Study," al-Qanțara 31 (2010): 103-147.

E.g. al-Muhallab b. Abī Ṣufra, Aslam b. Zur'a al-Kilābī (d. after 61/68o). 
but not necessarily governmental positions were also regular recipients of land grants: tribal leaders, ${ }^{58}$ companions of the prophet Muhammad ${ }^{59}$ and other figures with religious standing, ${ }^{60}$ family members, mawāli and supporters of the caliphs..$^{61}$ In general, most if not all of these individuals seem to be closely related to those in power, and very few if any are linked to their political opponents. It is hard to tell if this reflects a bias of our sources to the milieu in which they were written, or a reality.

The relation between landholding and government functions is ambiguous. On the one hand, high officials are obvious candidates to receive land grants as rewards for their service, but on the other hand, persons from the landholding elite which was created in this way became more eligible for government service through their social and political networks. Especially successful in collecting land grants were the families of Ziyād b. Abīhi, Abū Bakra, Abū al-'Āṣi alThaqafi (the leading family of the tribe Thaqif), the Muhallabids, and the great Abbasid governors' family of Sulaymān b. 'Alī. These and some other families gradually formed an urban-based landholding elite. This elite was pretty stable, although some of the landholding families lost their properties after falling out with the authorities, or after the Abbasids took over from the Umayyads. ${ }^{62}$ The Muhallabids, for example, saw all their possessions confiscated by Yazìd $b$. 'Abd al-Malik (r. 101-105/720-724), and they ended up in the hands of Yazìd's brothers' sons. Under the first Abbasid caliph, Abū al-'Abbās (r. 132-136/750754), these Marwanid possessions were again confiscated. Some of these were returned to a branch of the Muhallabid family, other estates were granted to Abū al-'Abbās' uncle, Sulaymān b. 'Alī, who was made governor of Basra (in office $133^{-139 / 750-756) . ~ M o s t ~ o f ~ t h e ~ o t h e r ~ o l d ~ l a n d h o l d i n g ~ f a m i l i e s ~ o f ~ U m a y y a d ~}$ times must have managed to hold on to their possessions after the Abbasid takeover as well. The Abbasids do not appear to have confiscated other lands than those that belonged to the grandsons of 'Abd al-Malik. ${ }^{63}$

58 E.g. the family of Abū al-'Āṣī al-Thaqafí, Suwayd b. Manjūf.

59 E.g. Ma'qil, Abū Bakra, Anas b. Mālik.

6o E.g. Jubayr b. Hayya (d. under 'Abd al-Malik b. Marwān), Kulthūm b. Jabr (d. 13o/747).

61 E.g. the Umayyad Asīd family; and mawā̄ì and family of Abū Bakr, 'Uthmān, and alManșūr. In general, most if not all of these individuals seem to be closely related to those in power, and very few if any are linked to their political opponents. It is hard to tell if this reflects a bias of our sources to the milieu in which they were written, or a reality.

62 See Morony, "Social Change."

63 In his Ansāb al-Ashrāf, al-Balādhurī states that Basra was an exception in this, and attributes this to the attitude of governor Sulaymān b. 'Alī. As an example, he relates how Sulaymān b. 'Alī was reluctant to confiscate the lands of some of the staunchest Umayyad allies, the family of the former governor Ziyād b. Abīhi (al-Balādhurī, Ansāb, ed. al-Dūrī, 
The information about the land grants in al-Balādhurīs list becomes very thin after the Abbasids' rise to power. We only hear of some large scale projects by the governor Sulaymān b. 'Alī and the caliph al-Manșūr, in whose reign the last two main canals of the west bank of the Dijla al-'Awrä' were dug (the Nahr al-Amīr and Nahr Abī al-Khașīb). According to Morony, this decrease of the reclamation effort may have had to do with the "development reach[ing] the point of diminishing return" by the end of the second/eighth century. ${ }^{64}$ Our discussion of Ibn Sarābiyūn's description of the canals of Basra seems to confirm and flesh out Morony's hypothesis, since we found it is likely that most of the land on the west bank of the Dijla al-'Awrä' had been reclaimed by the end of the second/eighth century. An alternative reason for the decrease of postUmayyad land grants in the list could be that al-Balādhurī's sources (most of whom died in the first half of the third/ninth century) ${ }^{65}$ did not comment on more recent developments, and al-Balādhurīs text gives us a false impression of a slump in the reclamation effort.

\section{5}

\section{The Problem of the Work Force and al-Tabarīs Account of the Revolt of the Zanj}

The lands that were developed by the Muslims on the west bank of the Dijla al-Awrä' appear to have been dead land, which means they had been abandoned since time immemorial. Since peasants were probably attached to the soil they tilled in Sasanian Iraq, this implies that there was also no work force available in the area. One of the important questions is thus: where did the new landholding elite find the workforce to work this huge area of newly reclaimed land? They surely did not work the land with their own hands. There is also no evidence of less fortunate Arabs settling in the Sawād as farm workers in the wake of the conquest. As for the local people (al-Nabat): it seems likely that many peasants were displaced as a consequence of the monster floods in 628 that ravaged a large part of the southern Sawād, combined with the chaos

124f.). See also the Umayyad estates around Medina being confiscated at the Abbasid takeover as discussed by Harry Munt in this volume.

64 Morony, "Social Change," 217.

65 al-Qaḥdhamī d. ca. 222/837, al-Madāinī ca. 225/840, Hishām b. al-Kalbī ca. 205/820, Abū 'Ubayda ca. 209/824, al-Athram ca. 261/875, Muhammad b. Sa'd ca. 23o/845, Rūh b. 'Abd al-Mu’min ca. 234/849, Abū al-Yaqzān ca. 19o/8o6, al-Dallāl al-'Aqawī ca. 221/836; see Khayr al-Dīn al-Ziriklī, al-A' lām (Beirut: Dār al-'ilm li-al-malāyīn, 1980) and 'Umar Kaḥhāla, Mujam al-Mu'allifin (Damascus: Mu’assasat al-risāla, 1957) under the relevant headings. 
created by the conquest. ${ }^{66}$ Some of these may have fled southwards, and they and their offspring may have been employed in the lands of the Basra area that were reclaimed in the following decades. Apart from the peasants that were bound to the ground, we know there were also groups of landless farm workers, who roamed the land in search of work (akara, hawāsid), who might have been brought to the reclaimed lands. ${ }^{67}$ We do not have any specific evidence for this kind of labor migration to the Basra area, though.

Another promising group of possible laborers are prisoners of war. The Sasanians routinely transported captives deeply into their empire to use them as labor force or for their specialized knowledge (e.g. waterworks, textiles). ${ }^{68}$ This practice was not unknown to the early Muslims. After the Riḍda wars, which brought all the Arabian tribes under the authority of the Muslims in the years immediately following Muhammad's death, thousands of prisoners of war were employed in an estate of Mu'āwiya in al-Yamāma. ${ }^{69}$ Anastasius of Sinai (d. after 700 ) also refers to Christian prisoners of wars employed in forced agricultural labor on public lands in the Dead Sea area. ${ }^{70}$ But again, there is no direct evidence for the settling of large amounts of captives as agricultural laborers in lower al-'Irāq.

Two groups of imported laborers are, however, known from the sources in the Basra area. The first consist of the Sayābija and Zuțt from Sind (present-day Pakistan). These appear to have been introduced into the marshes of lower Iraq

66 While we have reports on fugitives from battles and on Persian aristocrats fleeing the cities they lived in (Michael Morony, "The Effects of the Muslim Conquest on the Persian Population of Iraq," Iran 14 (1976): 48-49), there is no direct evidence of large-scale land flight in the area during the conquest. Such evidence is available for a later period, under alHajjāj, who seems to have engaged in a number of draconian ways to force farmers to stay on or go back to their lands. For the dramatic effects of the Tigris shift on the population, see Verkinderen, Waterways, 54 .

67 Kurt Franz, Kompilation in arabischen Chroniken: die Überlieferung vom Aufstand der Zanğ zwischen Geschichtlichkeit und Intertextualität vom 9. bis im 15. Jahrhundert (Berlin: De Gruyter, 2004), 42.

68 For example, the textile industry (e.g. al-Mas'ūdī, Murūj al-dhahab, ed. and trans. Charles Barbier de Meynard and Pavet de Courteille (Paris: Imprimérie Impériale, 1861-1877), 2:186) and the dams of Khūzistān (e.g. al-Ya'qūbī, Ta’rīkh (Beirut: Dār Ṣādir, 196o), 1:159) were often credited to captives from the Roman Empire resettled by Sasanian kings.

69 al-Balādhurī, Ansāb, 7:173.

70 See Robert Hoyland, "New Documentary Texts and the Early Islamic State," Bulletin of the School of Oriental and African Studies 69, no. 3 (2006): 402, n. 37. See also Robert Hoyland, Seeing Islam as Others Saw it (Princeton: Darwin Press, 1997), 596. n. 9 for more Christian and epigraphic sources mentioning large numbers of prisoners of war taken by the Muslims during the conquests. 
already in the Sasanian period, and after the Islamic conquest of Sind, thousands of Zutt were brought to Iraq, where al-Hajjāj settled them in the reeds of al-Batịha. Yazīd b. al-Muhallab used a large number of them, together with their water buffaloes which had accompanied them, to reclaim his immense estates in al-Batâa'ih. They revolted a number of times, and were deported to the Byzantine border. ${ }^{71}$ With their water buffaloes they would have been perfectly capable of reclaiming marshland and/or cultivating water-intensive crops like rice and sugar cane.

The other group consists of black slaves, called Zanj, who were first mentioned in the Basra district in 70/689, when they staged a revolt in Furāt alBașra, on the east bank of the Dijla al-'Awrā'. These black slaves were apparently employed in a different kind of reclamation. They had to remove (kașaha, lit. "sweep") the salt crust (shüraj) from the salt flats (sabkha, sibākh) that were located on both sides of the Dijla al-'Awrä. Kurt Franz made the interesting observation that the Zanj are never depicted as cultivating the estates they reclaimed. Perhaps the owners of the estates employed one of the other groups mentioned above to till the ground the Zanj had reclaimed..$^{72}$ Their employers, city folk from Basra, were called shürajizyūn, "salt-men," and made their slaves work the salt flats in horrible conditions. After two more unsuccessful rebellions in $75 / 694$ and $143 / 76$ o, they rose up a fourth time in $255 / 870$. This time, the revolt was led by a Persian man who claimed 'Alid descent, and lasted for many years. The Zanj defeated army after army that first the Basrans and then the caliph sent against them, conquered most of lower Khūzistān, Basra and al-Bațầih, and plundered the city of Basra. They were finally defeated after a 15-year long struggle that ravaged the entire area of Basra, which would never fully recover. ${ }^{73}$

The episode of the great Zanj rebellion in the third/ninth century is not only interesting because of its far-reaching consequences for the welfare of the region, but also because a very detailed account of the revolt is conserved in al-Ṭabarî’s History. ${ }^{74}$ Al-Ṭabarī's account, which is based on a memoir writ-

71 For a recent full overview of the sources on the Zuțt and Sayābija in al-'Trāq, see Franz, Kompilation, 44-46.

72 Franz, $5^{2}$.

73 Alexandre Popovic, "La révolte des esclaves en Iraq au IIIe et Ive siècle" (PhD diss., Librairie Orientaliste Paul Geuthner, 1976) has long been the standard work on the revolt of the Zanj, but has now been largely superseded by Kurt Franz's incisive study. See also Hugh Kennedy, "Caliphs and their Chroniclers in the Middle Abbasid Period (Third/Ninth Century)," in Texts, Documents, and Artefacts: Islamic Studies in Honour of D.S. Richards, eds. Donald S. Richards and Chase F. Robinson (Leiden: Brill, 2003), 18-35. 
ten by one of the confidants of the leader of the Zanj, gives us the most detailed description of a rural area extant in the whole of early Islamic literature. Especially the first two months of the revolt are described on an almost hour-to-hour basis, apart from a lacuna of about fourteen days, "during which [the Lord of the Zanj did] nothing spectacularly horrible considering the fact that everything he did was horrible," 75 and a few minor chronological breaks. ${ }^{76}$ We can follow the lord of the Zanj, 'Alī b. Muhammad, on his journey through much of the east bank of the Dijla al-'Awrā', raising support among the black slaves, capturing their overseers, and fighting the first local armies trying to stop them. Subsequently, we see them cross the Dijla al-'Awrā' and march from the southernmost canal, Nahr al-Qindal, up to the city of Basra. The story is filled with geographical details that give us many clues about the geographical situation of the area as it was in the mid-third/ninth century, i.e., more than 50 years after the last qațīa mentioned in al-Balādhurī's work.

There is no place here to go deeply into the layout of the canals. We will limit ourselves to some remarks. First, the main canals mentioned by Ibn Sarābiyūn are also found in al-Ṭabarī's text. Apart from these canals, al-Ṭabarì's account mentions dozens of canals that do not figure in any other source. Some of these branched off from the Dijla al-'Awrā' as the main canals did, others linked the main canals together. Especially the account of the final chapter of the Zanj revolt, ${ }^{77}$ the siege of their capital al-Mukhtāra (located on Nahr Abī al-Khașīb on the west bank of the Dijla al-'Awrâ'), sketches a veritable mesh of small canals that crisscrossed the area between the main canals.

The presence of fixed bridges (qanattir) across many of the canals ${ }^{78}$ suggest a developed road system, at least parallel to the Dijla al-'Awrä. The banks of the river were lined with palm groves ${ }^{79}$ - as they still are today - , and behind these, there were cultivated fields along the canals, but also salt flats $(s i b \bar{a} k h),{ }^{80}$

75 al-Ṭabarī, 3:1765.

76 See Peter Verkinderen, “Tigris, Euphrates, Kārūn, Karkhe, Jarrāhī: Tracking the Traces of 5 Rivers in Lower al-'Irāq and Khūzistān in the Early Islamic Period," (PhD diss., University of Gent, 2009), 218-233 and 441-456. Of course, it cannot be excluded that this flawless chronological narrative is a fabrication by the author; but at least a part of the route of the Zanj can be verified through a comparison with al-Ṭabarîs description of the battle of Maskin (ibid. 231 f.).

77 al-Ṭabarī, Tärīkh, 3:1982-2098.

78 al-Ṭabarī, 3:176o, 1763, 1779f., 2032, 2046 (but contrast with al-Ṭabarī, 3:1865).

79 al-Ṭabarī, 3:1776, 1769, 1775, 1785, 1834, 1994, 203o, 2059, 2095.

8o al-Ṭabarī, 3:1761-1763, 1773, 1776, 1786, 1872, 1994. 
areas that had not been brought under cultivation, and reed marshes (äjām, sg. ajama), ${ }^{81}$ probably areas where the water from the canals that had not been used up for irrigation gathered.

Few of the names of the canals can be linked with persons we know from the sources, but the presence of the Abbasids (most often called Hāshimīs in the text) as landholders appears to be very strong, especially on the east bank of the river. One of the canals on the east bank was called al-'Abbāsī al-Atìq, "the old Abbasid (canal)".82 On the al-Sîb canal was the village alJaffariyya, named after a Hāshimī, Jacfar b. Sulaymān, who must be the son of the patriarch of Basra's Abbasid governors' family, Sulaymān b. 'Alī. This Ja'far himself was also governor of Basra for a short time in 176/792. ${ }^{83}$ The lord of the Zanj spent the night in Ja'far b. Sulaymān's house, in a second house belonging to a Hāshimī they found a weapons cache, and the Zanj also captured a mawlā of the Zaynabī family, the most powerful branch of the same Abbasid family. ${ }^{84}$ In two other villages a bit further to the south, al-Qādisiyya and Shîfiyya, the Zanj captured another mawlā of the Hāshimīs. ${ }^{85}$ The east bank canal 'Amūd Ibn al-Munajjim ${ }^{86}$ was named after one of the descendants of the astrologer (munajjim) Mūsā b. Shākir, a protégé of al-Ma'mūn. Two of Mūsā b. Shākir's sons were involved in the digging of the canals of alMutawakkil's new city al-Ja fariyya near Sāmarrā. ${ }^{87}$ Another east bank canal ${ }^{88}$ was named after al-Ḥasan b. Muhammad b. Abī Shawārib, the chief judge of Iraq, appointed in the year 252/866, only three years before the outbreak of the revolt. The Nahr Bard al-Khiyār ${ }^{89}$ was named after Muhammad b. 'Alī Bard al-Khiyār, who was in charge of the dīwān al-diy $\bar{a}$, the ministry of estates, at the time of or just before the revolt. ${ }^{90} \mathrm{~A}$ canal on the east bank of the Tigris was named al-Khayzurāniyya, after the Abbasid caliph al-Mahdī's wife, al-Khayzurān (d. 173/789), ${ }^{91}$ and another one, very close to it, ${ }^{92}$ derived its name




from her secretary 'Umar b. Mihrān. ${ }^{93}$ Abū Manșūr al-Zaynabī, the most powerful scion of the Abbasid family in Basra at the outbreak of the Zanj rebellion, had a castle with a garrison on the bank of the Nahr al-Qindal, the southernmost main canal on the west bank. ${ }^{94}$ This is the only "new" west bank canal related to the Abbasids I can identify in al-Tabarīs account. The most telling sign of the heavy involvement of the Abbasids in the land reclamation and landholding is, however, al-Tabari’s note that the leader of the Zanj on the eve of the revolt settled in a castle on the east bank of the Dijla al-'Awrä', and in order not to raise any suspicion, gave out he was an agent of the sons of caliph al-Wāthiq, responsible for the sale of sibākh. ${ }^{95}$ This cover only makes sense if the caliphal family was heavily involved in the reclamation effort.

It is thus obvious that the grants of qața $i^{\prime}$ had not stopped after the Abbasid takeover. The grantees we can identify are closely related to the Abbasid inner circle. One notable difference with the Umayyad period appears to be that the Abbasids apparently tended to grant lands in the Basra area not only to local powerhouses, but also to important figures in the central government in Baghdad and Sāmarrā̄. And a second important difference is the fact that almost all of these new Abbasid land grants we identified in al-Ṭabarīs account appear to have been located on the east bank of the river. This supports our suggestion that the decrease of the land grants on the west bank of the Dijla al-'Awrä' in the early Abbasid period was related to the fact that most of the profitable lands of the west bank of the river had already been reclaimed. This does not mean that reclamation did not continue on the west bank at this time. At least in two places, al-Tabarī relates how the lord of the Zanj captured numbers of Zanj, "slaves of the shürajiyyün," from their owners in the area south of Basra at the beginning of the revolt. ${ }^{96}$

To conclude this paper, we will consider some questions related to the balance between "state" and "private" investment in the reclamations in the region around Basra.

93 'Umar b. Mihrān functioned as al-Khayzurān's secretary until he was appointed governor of Egypt in 176/792-793 (see al-Ṭabarī, Tảrïkh, 3:626f.).

94 al-Ṭabarī, 3:1774.

95 al-Ṭabarī, 3:1754.

96 al-Ṭabarī, 3:1773f., 1775 f. 
State investment in land reclamation is defined in this paper as irrigation and drainage works that are (1) entirely paid for (from taxes) and/or carried out by the state (e.g., through corvée work or other types of forced labor, e.g., by slaves or prisoners) and (2) result in the creation of state land, all proceeds of the cultivation of which go directly to the state (after the deduction of the share of sharecroppers, managers, etc.). If land reclaimed by an individual becomes as a result his private property (mulk) that can be sold and inherited, and the state only receives a return on the individual's investment through the 'ushr tax paid by the owner, I do not consider this a state project, but a "private" project, even if the owner in question is a state official. With the admittedly anachronistic term "private" investments, we thus refer to investments made by individuals, whatever their rank or position, primarily for their own profit, not for the state's coffers (even if the state profited along by way of taxes).

We have seen that, unlike in other parts of the Sawād, the state does not seem to have engaged in such direct investments in the development of agriculture in the Basra area. There are no reports about governors or the central government reviving dead lands to create state lands, cultivated for the state. The only canals dug by the governors of Basra in their official function appear to be those that, according to the sources, were aimed at bringing sweet water to the city Basra (Nahr al-Ubulla, Nahr Ma'qil, Nahr Ibn 'Umar). ${ }^{97}$ These drinking-water canals were not small aquaducts but some of the largest waterways in the area. They were obviously not only used to bring fresh water to the city. The lands along these canals were granted to private persons, and the area between the two main canals constructed to supply water to Basra, Nahr Ma'qil and Nahr alUbulla, became world famous because of its rich date palm gardens. ${ }^{98}$ It is not improbable that this creation of qați ${ }^{-} a$ land was at least as important a reason for the digging of these canals as improving the water quality of the inhabitants of Basra, even if this is not explicitly mentioned in the sources.

The line between private and state investment in the reclamation of the lands of Basra is blurred by the fact that most of the people who reclaimed lands

97 For an overview of the canal digging activities in the Basra area, see Verkinderen, Waterways, 66-107.

98 E.g. al-Ișțakhrī, Kitāa al-Masālik wa-al-mamālik, ed. Michael Jan de Goeje (Leiden: Brill, 1870), 81; al-Muqaddasī, Ahssan al-taqāsim fì márifat al-aqālīm, ed. Michael Jan de Goeje (Leiden: Brill, 1887), 35; al-Idrīsī, Nuzhat al-Mushtāq, ed. Enrico Cerulli et al. (Napoli/ Roma: Istituto Universitario Orientale, 1970), 384; al-Dimashqī, Nukhbat al-dahr, ed. August Ferdinand Mehren as: Cosmographie de Chems-ed-Din Abou Abdallah Mohammed ed-Dimichqui (St.-Petersburg: Académie Royale des Sciences, 1923), 97; Abū al-Fidā', Taqwìm al-buldān, ed. Joseph Toussaint Reinaud and William McGuckin de Slane as: Géographie d'Aboulfeda (Paris: Imprimerie Royale, 1840), 56. 
in the area were high Umayyad and Abbasid officials. The relationship between land ownership and important government positions is not linear, since almost all estates were reclaimed by people close to power, while the class of land owners created by the land grants and reclamations became the very elite from which most of the officials of the (provincial) government were chosen.

A crucial question remains, namely who initiated the land reclamations, private persons wanting to make money by investing in agriculture, or the state, wanting to maximize its tax income? Difficult to answer, there are some clues that point in the direction of the primacy of private initiative. According to al-Balādhurī, the first person in Basra to receive a land grant was Ziyād's half brother Nāfi' b. al-Ḥarith al-Thaqafi, who had asked the caliph 'Umar for a piece of land located along the Dijla al-'Awrā' in order to raise horses. ${ }^{99}$ Moreover, there was a debate among the jurists about the question if dead land could be reclaimed without the permission of the authorities. The Shāfi' ì school adhered to the opinion that it was allowed, while Abu Hanifa, always in favor of giving the ruler the ultimate right of choice, ${ }^{100}$ considered it forbidden. ${ }^{101}$ That the reclamation of dead land took place more often without than with permission, is suggested by a quote of Ibn Shubruma, ${ }^{102}$ mentioned by al-Balādhurī:

If I were governor of Basra, I would confiscate the property of its inhabitants, because (the second caliph) 'Umar b. al-Khatțāb only granted land in Basra to Abū Bakra and Nāfi' b. al-Ḥārith, and (the next caliph) 'Uthmān only to 'Imrān b. Ḥuṣayn, (the governor of Basra) Ibn 'Āmir - to whom he gave his house - , and his mawlā Ḥumrān (b. Abān).103

Al-Balādhurī even mentions a number of cases in which private persons reclaimed land for themselves in an area that was granted to a third person by the caliph (e.g. al-Marghāb and Nahr Yazīd). ${ }^{104}$ The jurists unanimously agree that even if someone has already started the reclamation but has not finished it (e.g., the boundaries have been marked but the land has not been drained yet), someone else may still start working on the land, and if the second person

\footnotetext{
99 al-Balādhurī, Futūh, 35of.

100 Confront, for example, Abū Hanīfa's ideas about the division of the ghanima (al-Māwardī, Ahkām, 237 f.) or the lawful receivers of an iqțā istighlāl (al-Māwardī, Aḥkām, 337) with those of al-Shāfici (d. 204/820) and Mālik (d. 179/796).

101 al-Māwardī, Ahkām, 308, 33 .

102 'Abd Allāh b. Shubruma, qā dī of Kūfa, d. 144/761, see al-Dhahabī, Siyar a lām al-nubalā', ed. Shu'ayb al-Arna’ūt (Damascus and Beirut: Mu’assasat al-risāla, 2001), 6:347-349.

103 al-Balādhurī, Futūh, 351.

104 al-Balādhurī, 364 f.
} 
completes the reclamation, the land becomes his property, and the first person loses his rights to it. ${ }^{105}$ One wonders if it is more than a coincidence that only in a small minority of the entries in al-Balādhurī's list of canals, land grants and estates a granter is mentioned. Is this perhaps because many of these estates were reclaimed by people without permission? On the other hand, al-Balādhurī also mentions a case in which a mawlā of Ziyād b. Abīhi forged a document stating that a grant had been awarded to him by Yazīd b. Mu'āwiya. ${ }^{106}$ Perhaps the jurists' near-consensus about the legality of reclaiming dead lands without permission of the ruler is a later (post-Umayyad?) development, regularizing a widespread practice.

On another level, even if the initial impetus for the reclamation of dead lands is to be found in the initiative of private entrepreneurs, the fact that reclaimed lands paid only the 'ushr tax can be interpreted as a fiscal stimulus created to encourage private reclamation of land, a tax cut for investment in agricultural development, as it were. The state thus appears to have fostered investments in irrigation projects in two ways: by granting dead lands to its supporters, and by offering a favorable tax arrangement to people who reclaimed land.

It could also be argued that by bringing these lands under cultivation, under the ownership of its supporters, the state established a strong control over the countryside of Basra. However, if this was a goal of state policy, it backfired spectacularly in the mid-third/late ninth century, when the revolt of the Zanj slaves, brought in by the investors, devastated the area and Basra never really recovered.

\section{Bibliography}

\section{Primary Sources}

Abū al-Fidā' (d. 731/1331). Taqwìm al-buldān. Edited by Joseph Toussaint Reinaud and

William McGuckin de Slane as: Géographie d'Aboulfeda. 2 vols. Paris: Imprimerie Royale, 1840.

Abū Yūsuf (d. ca. 181/798). Kitāb al-Kharāj. Cairo: al-Mațbaca al-Salafiyya, 1933. al-Balādhurī (d. ca. 278/892). Kitāb Futūḥ al-buldān. Edited by Michael Jan de Goeje as: Liber expugnationis regionum. Leiden: Brill, $1968^{2}$.

al-Balādhurī. Ansāb al-ashräf. Edited by Suhayl Zakkar and Riyāạ Ziriklī. 13 vols. Beirut:

Dār al-Fikr, 1996.

105 al-Māwardī, Ahkām, $319 \mathrm{f}$.

106 al-Balādhurī, Futūḥ, 369. 
al-Balādhurī. Ansāb al-ashrāf. Edited by 'Abd al-'Azīz al-Dūrī. Beirut and Wiesbaden: Deutsche Morgenländische Gesellschaft, 1978.


Damascus and Beirut: Mu'assasat ar-Risāla, 2001.

al-Dimashqī (d. 727/1327). Nukhbat al-dahr. Edited by August Ferdinand Mehren as: Cosmographie de Chems-ed-Din Abou Abdallah Mohammed ed-Dimichqui. St.-Petersburg: Académie Royale des Sciences, 1923.

Ibn 'Abd al-Ḥaqq al-Baghdādī (d. 739/1338). Marāṣid al-iț̣ilā' ' alā asmā’ al-amkina waal-biqā' . Edited by 'Alī Muḥammad al-Bijāwī. Beirut: Dār al-Ma'rifa, 1954.

Khalīfa b. Khayyāt (d. 239/854). Ta’rīkh. Edited by Mușțafā Najīb Fawwāz and Hikmat Kishlī Fawwāz. Damascus: Mu’assasat al-Risāla, 1995.

al-Ḥāzimī (d. 583/1188). Mā ittafaqa lafžuhu wa-iftaraqa musammāhu fi al-amākin waal-buldān al-mushtabiha fi al-khațt. Edited by Fuat Sezgin as: Kitāb al-Amākin. Frankfurt am Main: Institut für die Geschichte der Arabisch-Islamische Wissenschaften, 1986.

Ibn al-Faqīh al-Hamadhānī (d. after 29o/903). Kitāb al-Buldān. Edited by Michael Jan de Goeje as: Compendium Libri Kitāb al-Buldān. Leiden: Brill, 1885.

Ibn al-Faqīh al-Hamadhānī. Kitāb al-Buldān (Mashhad ms.). Edited by Zacharias van Laer as: Het boek van de geschiedenis der Landen. 2 vols. Brussels: author's edition, 1985.

Ibn Ḥawqal (d. after 377/988). Kitāb Șūrat al-arḍ. Edited by Johan Hendrik Kramers as: Liber Imaginis Terrae. Leiden: Brill, 1938.

Ibn Ḥazm al-Andalusī (d. 456/1064). Jamharat ansāb al-'arab. Edited by Évariste LéviProvencal. Cairo: Dār al-Ma'ārif, 1948.

Ibn Rusta (d. after 30o/913). Kitāb al-A'lāq al-nafisa. Edited by Michael Jan de Goeje as: Kitāb al-a lāk an-nafı̌sa VII / auctore Abū Alī Ahmed ibn Omar Ibn Rosteh et Kitāb al-boldān / auctore Ahmed ibn abì Jakūb ibn Wādhih al-Kātib al-Jakūbī. Leiden: Brill, 1892.

Ibn Sarābiyūn (d. after 333/945). Kitāb 'Ajāỉb al-aqālim al-sab'a. Edited by Hans von Mžik as: Kitāb 'ajāib al-aqālìm al-sab'a des Suhrāb, herausgegeben nach dem handschriftlichen Unikum des Britischen Museums in Londen /cod. 23379 add./. Leipzig: Harassowitz: 1929 .

al-Idrīsī (d. ca. 56o/1165). Nuzhat al-Mushtāq. Edited by Enrico Cerulli et al. as: Opus geographicum sive liber ad eorum delectationem qui terras peragrare student. 9 vols. Naples/Rome: Istituto Universitario Orientale, 1970.

al-Iștakhrī (wrote ca. 338/950). Kitāb al-Masālikwa-al-mamālik. Edited by Michael Jan de Goeje as: Viae regnorum: descriptio ditionis moslemicae. Leiden: Brill, 1870.

al-Mas'ūdī (d. 344/956). Murūj al-dhahab. Edited and translated by Charles Barbier de Meynard and Pavet de Courteille as: Les Prairies d'Or. Paris: Imprimerie Impériale, $1861-1877$. 
al-Māwardī (d. 449/1058). al-Aḥkām al-sulțāniyya. Edited by Maximilianus Enger as: Maverdii Constitutiones politicae. Bonn: Adolphus Marcus, 1853.

al-Muqaddasī (d. after 379/99o). Aḥsan al-taqāsim fìmárifat al-aqālìm. Edited by Michael Jan de Goeje as: Descriptio Imperii Muslemici. Leiden: Brill, 1887.

al-Qāḍī al-Tannūkhī (d. 384/994). Nishwār al-muhạạarar. Edited by 'Abūd Shaljī. 8 vols.

Beirut: 'Ālam al-Kutub, 1971-1973.

Qudāma b. Jacfar (d. ca. 319/932). Kitāb al-Kharāj. Edited and translated by Aharon Ben Shemesh as: Taxation in Islam 2: Qudāma b. Jaffar's Kitāb al-Kharāj, part seven, and excerpts from Abū Yūsuf's Kitāb al-Kharāj. Leiden: Brill, 1965.

Qudāma b. Ja'far. Kitāb al-Kharāj. Edited by Michael Jan de Goeje as: Liber viarum et regnorum: et excerpta e Kitab al-kharadj. Leiden: Brill, 1967.

al-Ṭabarī (d. 310/923). Mukhtașar ta’rīkh al-rusul wa-al-mulūkwa-al-khulafä. Edited by Michael Jan de Goeje as: Annales quos scripsit Abu Ga'far al-Tabari. Leiden: Brill, 1964.

Yaḥyā b. Ādam (d. 202/818). Kitāa al-Kharāj. Edited and translated by Aharon Ben Shemesh as: Taxation in Islam ı: Yahyya ben Ādam's Kitāb al-Kharāj. Leiden: Brill, $195^{8}$. al-Ya'qūbī (d. after 292/905). Ta’rīkh. Beirut: Dār Șādir, 196o.

Yāqūt al-Rūmī (d. 626/1229). Mu'jam al-buldān. Beirut: Dār Șādir, 1955.

\section{Secondary Sources}

Adams, Robert M. Land Behind Baghdad: A History of Settlement on the Diyala Plains. Chicago/London: University of Chicago Press, 1965.

Adams, Robert M. "Settlement and Irrigation Patterns in Ancient Akkad." In The City and Area of Kish, edited by McGuire Gibson, 182-208. Coconut Grove, FL: Field Research Projects, 1972.

Adams, Robert M. Heartland of Cities: Surveys of Ancient Settlement and Land Use on the Central Floodplain of the Euphrates. Chicago/London: University of Chicago Press, 1981.

Buringh, Pieter. Soils and Soil Conditions in Iraq. Baghdad: Ministry of Agriculture, 196o.

Cahen, Claude, "Iḳtāa." In Encyclopaedia of Islam, 2nd edition. Edited by P. Bearman, Th. Bianquis, C.E. Bosworth, E. van Donzel and W.P. Heinrichs. Leiden: Brill. http:// dx.doi.org/10.1163/1573-3912_islam_SIM_3522.

Donner, Fred M. The Early Islamic Conquests. Princeton: Princeton University Press, 1981.

Ebstein, Michael. "Shurța Chiefs in Bașra in the Umayyad Period: A Prosopographical Study." al-Qanțara 31 (2010): 103-147.

Franz, Kurt. Kompilation in arabischen Chroniken: die Überlieferung vom Aufstand der Zanğ zwischen Geschichtlichkeit und Intertextualität vom 9. bis im 15. Jahrhundert. Berlin: De Gruyter, 2004. 
Gibson, McGuire. The City and Area of Kish. Coconut Grove, F L: Field Research Projects, 1972.

Graadt van Roggen, Diederik Lucas. "Notice sur les anciens travaux hydrauliques en Susiane." Mémoires de la Délégation en Perse 7 (1905): 168-207.

Hill, Donald R. "Mūsā, banū." In Encyclopaedia of Islam, 2nd edition. Edited by P. Bearman, Th. Bianquis, C.E. Bosworth, E. van Donzel and W.P. Heinrichs. Leiden: Brill. http://dx.doi.org/10.1163/1573-3912_islam_SIM_5557.

Hoyland, Robert. Seeing Islam as Others Saw it. Princeton: Darwin Press, 1997.

Hoyland, Robert. "New Documentary Texts and the Early Islamic State." Bulletin of the School of Oriental and African Studies 69, no. 3 (2006): 395-416.

Kaḥhāla, 'Umar. Mu'jam al-Mu’allifin. Damascus: Mu’assasat al-Risāla, 1957.

Katbi, Ghaida Khazna. Islamic Land Tax al-Kharāj: From the Islamic Conquests to the Abbāsid Period. London: I.B. Tauris, 2010.

Kennedy, Hugh. "Caliphs and their Chroniclers in the Middle Abbasid Period (Third/ Ninth Century)." In Texts, Documents, and Artefacts: Islamic Studies in Honour of D.S. Richards, edited by Donald S. Richards and Chase F. Robinson, 18-35. Leiden: Brill, 2003 .

Kennedy, Hugh. The Great Arab Conquests. Philadelphia: Da Capo Press, 2007.

Kennedy, Hugh. "The Feeding of the 500.00o: Cities and Agriculture in Early Islamic Mesopotamia." Iraq 73 (2011): 177-199.

Løkkegaard, Frede. Islamic Taxation in the Classic Period. Copenhagen: Branner og Korch, 195 o.

Morony, Michael. "The Effects of the Muslim Conquest on the Persian Population of Iraq." Iran 14 (1976): 41-59.

Morony, Michael. Iraq after the Muslim Conquest. Princeton: Princeton University Press, 1984.

Morony, Michael. "Landholding and Social Change: Lower al-Irāq in the Early Islamic Period." In Land Tenure and Social Transformation in the Middle East, edited by Tarif Khalidi, 209-222. Beirut: American University in Beirut Press, 1985.

Nützel, Werner. "The End of the South Mesopotamian Civilizations Caused by the Bursting of the Dykes of the Euphrates and Tigris in 629 AD." Sumer 38 (1982): 144151.

Pellat, Charles. Le milieu bașrien et la formation de Ğăhiziz. Paris: Adrien-Maisonneuve, 1953.

Popovic, Alexandre. "La révolte des esclaves en Iraq au IIIe et Ive siècle." PhD diss., Paris: Librairie Orientaliste Paul Geuthner, 1976.

Pourshariati, Parvaneh. The Decline and Fall of the Sasanian Empire. London: I.B. Tauris, 2008.

Robinson, Chase F. "The Conquest of Khûzistân: A Historiographical Reassessment." Bulletin of the School of Oriental and African Studies 67 (2004): 14-39. 
Schmucker, Werner. Untersuchungen zu einigen wichtigen Bodenrechtlichen Konsequenzen der Islamischen Eroberungsbewegung. Bonn: Selbstverlag des Orientalischen Seminars der Universität Bonn, 1972.

Soroush, Mehrnoush. "Irrigation in Khuzistan after the Sasanians: Continuity, Decline or Transformation?" In The Long Seventh Century: Continuity and Discontinuity in an Age of Transition, edited by Alessandro Gnasso, 269-29o. Oxford: Oxford University Press, 2015.

Sousa, Ahmad. Rayy Sāmarrā’ fì 'ahd al-khilāfa al-'Abbāsiyya. Baghdad: Maṭba'at alMa'ārif, 1948.

Verkinderen, Peter. “Tigris, Euphrates, Kārūn, Karkhe, Jarrāhīi: Tracking the Traces of 5 Rivers in Lower al-'Irāq and Khūzistān in the Early Islamic Period." PhD diss., University of Gent, 2009 .

Verkinderen, Peter. Waterways of Iraq and Iran in the Early Islamic Period: Changing Rivers and Landscapes of the Mesopotamian Plain. London: I.B. Tauris, 2015.

al-Ziriklī, Khayr al-Dīn. al-A' $\bar{a} m$. Beirut: Dār al-'ilm li-al-malāyīn, 198o. 